\title{
Pemanfaatan MOL (Mikroorganisme Lokal) sebagai Substitusi Biostarter EM4 untuk Meningkatkan Kualitas Nutrisi Pakan Fermentasi Berbasis Tongkol dan Tumpi Jagung
}

\section{(Utilization of MOL (Local Microorganisms) as Substitution of EM4 Biostarter to Improve Nutritional Quality of Corn Cob and Tumpi- Based Fermented Feed)}

\author{
Khasanah $\mathrm{H}^{1}$, Purnamasari $\mathrm{L}^{1}$, Kusbianto $\mathrm{DE}^{2}$ \\ ${ }^{I}$ Program Studi Peternakan, Fakultas Pertanian, Universitas Jember \\ ${ }^{2}$ Program Studi Ilmu Pertanian, Fakultas Pertanian, Universitas Jember \\ himma@unej.ac.id
}

\begin{abstract}
Feed processing through fermentation technology can be applied to improve the quality of nutrients in feed. Jember is a district that has large agricultural production so that agricultural waste can be used as a ruminant feed in Jember Regency. The fermentation process requires a bioactivator, one of the microorganisms that can be used is local microorganisms (MOL). The purpose of this study is to analyze the influence of MOL to improve the quality of feed based on corn cob and corn tumpi. The ingredients used for feed are corn cobs, peanut rendeng, rice bran, urea, premix, and molasses. The fermentation process uses the SSF (Solid-state fermentation) method for 21 days with P0 is the control (EM 4); P1: MOL Cattle rumen; P2: MOL of rumen+banana hump; P3: MOL of rumen+Bamboo; P4: MOL of Gamal leaves. Fermented feed is analyzed its nutritional quality using proximate analysis. The results of this study show the lowest fermentation of crude fiber content of fermentation, namely P2 (17.52\%), P4 (18.30\%), P0 (18.70\%), P1 (20.05\%), and P3 $(20.65 \%)$. Consequently, the crude protein of the highest was P3 (4.01\%), P4 (3.80\%), P1 $(3.83 \%)$, P0 $(3.71 \%)$ and P2 (3.59\%) respectively. Fermentation of cob and corn tumpi feed using local microorganisms gives the same results as fermentation using EM4 commercial biostarter. The crude protein content of fermented corn cob and tumpi-based feed is still low.
\end{abstract}

Key words: Local microorganism, corncob, fermented feed, corn tumpi

\begin{abstract}
ABSTRAK
Pengolahan pakan melalui teknologi fermentasi dapat diaplikasikan untuk meningkatkan kualitas nutrisi dalam pakan. Jember merupakan Kabupaten yang memiliki produksi pertanian yang besar, sehingga limbah pertanian dapat dijadikan sebagai pakan ternak ruminansia di Kabupaten Jember. Proses fermentasi membutuhkan bioaktivator, salah satu mikroorganisme yang dapat digunakan adalah mikroorganisme lokal (MOL). Tujuan dari penelitian ini adalah manganalisis pengaruh MOL untuk meningkatkan mutu pakan berbasis tongkol dan tumpi jagung. Bahan yang digunakan untuk pakan adalah tongkol dan tumpi jagung, jerami kacang tanah, dedak padi, urea, premix dan molases. Proses fermentasi menggunakna metode SSF (Solid state fermentation) selama 21 hari dengan perlakuan P0: kontrol (EM 4); P1: MOL Rumen sapi; P2: MOL bonggol pisang; P3: MOL bambu; P4: MOL daun Gamal. Pakan hasil fermentasi dianalisis kualitas nutrisinya mengggunakan analisis proksimat. Hasil penelitian menunjukkan kandungan serat kasar konsentrat fermentasi dari yang terendah, yaitu P2 $(17,52 \%)$, P4 (18,30\%), P0 (18,70\%), P1 (20,05\%), dan P3 (20,65\%). Secara berturut-turut protein kasar dari yang tertinggi, yaitu P3 (4,01\%), P4 (3,80\%), P1 (3,83\%), P0 (3,71\%) dan
\end{abstract}


P2 (3,59\%). Fermentasi pakan berbasis tongkol dan tumpi jagung menggunakan mikroorganisme lokal memberikan hasil yang sama dengan fermentasi menggunakan biostarter komersial EM4. Kandungan protein kasar pakan berbasis tongkol dan tumpi jagung yang difermentasi masih rendah.

Kata kunci: Mikroorganisme lokal, pakan fermentasi, tongkol jagung, tumpi jagung

\section{PENDAHULUAN}

Pengembangan pakan alternatif melalui pemanfaatkan limbah pertanian yang memiliki nilai ekonomis sangat rendah dapat dilakukan dengan teknologi pengolahan fermentasi. Kabupaten Jember memiliki sumber pakan alternatif yang belum termanfaatkan dengan baik, yaitu dari tongkol dan tumpi jagung. Produksi pertanian tahun 2017 sebesar 960.602 ton dengan produk utama padi, jagung dan kacamg tanah. Limbah pertanian yang sudah dijadikan sebagai pakan alternatif ternak ruminansia adalah jerami padi, jerami jagung, jerami kacang tanah, pucuk tebu, dan beberapa hijauan hasil pertanian lainya (Imsya et al. 2017). Adapun keuntungan yang bisa didapatkan ketika menggunakan pakan berbasis limbah pertanian adalah: (1) mengurangi limbah dan ramah lingkungan, (2) memanfaatkan limbah pertanian, (3) meningkatkan perekonomian dan kesejahteraan peternak (Agustono et al. 2017). Kebanyakan peternak memberikan pakan seadanya tanpa adanya penimbangan dan tanpa memperhatikan kebutuhan ternak. Pakan yang diberikan juga tergantung dari rumput yang didapat saat mencari rumput setiap harinya (cut and carry) Meskipun peternak sudah mulai mengenal sistem menanam rumput, namun sebagian besar masih diperoleh dari hasil mencari rumput (cut and carry). Beberapa peternak di Kabupaten Jember menanam rumput dilahan kosong dan pematang sawah, adapun jenis rumput yang ditanam sebagai pakan ternak kambing adalah rumput Gajah (Pennisetum purpureum), rumput Benggala (Panicum maximum), rumput Kolonjono (Brachiaria mutica) yang ditanam di pematang sawah, sehingga jumlahnya masih sangat terbatas untuk memenuhi kebutuhan seluruh ternak. Terkadang peternak juga mencari rumput dan hijauan di area perkebunan karet milik PTPN XII. Limbah hasil pertanian seperti tumpi jagung dan tongkol jagung juga berpotensi diolah untuk menjadi pakan ternak. Namun peternak belum pernah memanfaatkan limbah tersebut sebagai pakan ternak (Khasanah 2017).

Biji jagung banyak dimanfaatkan sebagai sumber energi dan protein untuk ternak unggas maupun ruminansia. Tebon jagung juga sudah banyak dimanfaatkan sebagai pakan, baik diberikan secara langsung maupun dalam bentuk silase atau amoniasi (Umiyasih \& Wina 2015). Salah satu bagian tanaman jagung yang masih belum termanfaatkan secara optimal adalah tongkol jagung dan tumpi jagung (kulit biji hasil penggilingan). Padahal tongkol jagung ini merupakan biomassa yang besar, namun memiliki kandungan nutrisi yang sangat rendah; sehingga perlu pengolahan untuk meningkatkan kualitas tongkol jagung. Pakan fermentasi adalah salah satu teknik pengolahan pakan yang mampu meningkatkan kualitas nutrisi pakan.

Mikroorganisme lokal (MOL) banyak digunakan sebagai bioaktifator proses fermentasi pakan maupun pembuatan pupuk organik cair (POC). Mikroorganisme lokal biasanya dibuat dari beberapa bahan alami yang terdapat beberapa bakteri menguntungkan seperti bakteri Rhizobium sp., Azospirillum sp., Azotobacter sp., Pseudomonas sp. dan Bacillus sp. (Lindung 2015). MOL juga dapat meningkatkan kualitas nutrisi bahan pangan dan pakan, yaitu dapat meningkatkan protein kasar dan menurunkan serat kasar (Ginting \& Pase 2018). MOL dari rumen kerbau diketahui dapat meningkatkan kecernaan pelepah sawit fermentasi (Tafsin et al. 2018). Penggunaan MOL 
bambu muda untuk fermentasi limbah kulit nanas dapat digunakan pada pakan broiler tanpa menimbulkan efek negatif pada pertumbuhan, karkas dan organ (Heryadi et al. 2018). Pemanfaatan MOL sebagai probiotik untuk pakan silase limbah tanaman jagung dapat memberikan efek terhadap penurunan kandungan NDF (Neutral Detergent Fiber) dan kadar hemiselulosa (Yanti et al. 2018). Oleh karena itu, penelitian ini bertujuan menganalisis pengaruh MOL yang berbeda untuk meningkatkan mutu pakan ternak berbasis limbah pertanian yang tidak termanfaatkan menjadi bahan baku pakan yang ekonomis dan berkualitas.

\section{MATERI DAN METODE}

Penelitian ini dilakukan pada bulan November 2018 sampai Januari 2019 berlokasi di Laboratorium Agroteknologi Fakultas Pertanian Universitas Jember. Peralatan yang digunakaan dalam pembuatan MOL adalah toples plastik, hose, botol plastik, plastisin dan selotip. Bahan-bahan yang digunakan dalam pembuatan MOL, yaitu isi rumen sapi dari RPH (Rumah Potong Hewan), molases, bonggol pisang, rebung bambu, daun Gamal, air cucian beras dan air kelapa. Formulasi pembuatan MOL disajikan pada Tabel 1. Perbanyakan mikroba dilakukan dengan cara mencampurkan semua bahan ke dalam toples plastik dan dibiarkan selama 21 hari pada kondisi anaerob. Bahan-bahan yang digunakan dalam pembuatan pakan adalah limbah pertanian, yaitu tongkol jagung, tumpi jagung, jerami kacang tanah, dedak padi, molases, premix, urea, garam dan starter.

Tabel 1. Formulasi mikroorganisme lokal yang digunakan

\begin{tabular}{llllll}
\hline \hline Bahan/perlakuan & P0 (EM4) & $\mathrm{P} 1$ & $\mathrm{P} 2$ & $\mathrm{P} 3$ & $\mathrm{P} 4$ \\
\hline Isi rumen & - & $500 \mathrm{gr}$ & $500 \mathrm{gr}$ & $500 \mathrm{gr}$ & $500 \mathrm{gr}$ \\
Bonggol pisang & - & - & $1 \mathrm{Kg}$ & - & - \\
Rebung & - & - & - & $1 \mathrm{Kg}$ & - \\
Daun gamal & - & - & - & - & $1 \mathrm{Kg}$ \\
Molases & - & $100 \mathrm{ml}$ & $100 \mathrm{ml}$ & $100 \mathrm{ml}$ & $100 \mathrm{ml}$ \\
Air kelapa & - & $1 \mathrm{Liter}$ & $1 \mathrm{Liter}$ & $1 \mathrm{Liter}$ & $1 \mathrm{Liter}$ \\
Air cucian beras & - & 1 Liter & 1 Liter & 1 Liter & 1 Liter \\
\hline
\end{tabular}

Penelitian ini menggunakan biostarter yang berbeda, yaitu P0 adalah EM4, P1 adalah MOL isi rumen, P2 adalah MOL isi rumen+bonggol pisang, P3 adalah MOL isi rumen+rebung, P4 adalah MOL isi rumen+daun Gamal. Proses fermentasi dilakukan dengan cara mengeringkan tongkol jagung dan jerami kacang tanah melalui penjemuran matahari. Setelah kering, kedua bahan tersebut dihaluskan menggunakan hammer mill dengan saringan ukuran saringan nomor 4 kemudan disterilkan dengan autoklaf pada suhu $121^{\circ} \mathrm{C}$ selama 20 menit. Tongkol jagung, tumpi, dedak padi kemudian dicampur dengan Molases, starter (MOL), premix dan urea yang sebelumnya sudah dilarutkan dalam 10 liter air untuk $100 \mathrm{~kg}$ bahan ransum. Setelah semua bahan tercampur dengan homogen, kemudian dimasukkan ke dalam plastik silo dan dimampatkan, udara yang tersisa dihilangkan dengan cara divakum untuk menciptakan kondisi anaerob. Campuran ransum yang sudah dikemas kemudian difermentasi pada suhu ruang selama 21 hari. Selama proses fermentasi diamati warna, bau, tekstur dan ada tidaknya kontaminasi jamur. Setelah 21 hari, kualitas nutrisi pakan fermentasi dianalisis berdasarkan analisis proksimat (AOAC 2005) yaitu kadar bahan kering (BK), protein kasar (PK), serat kasar 
(SK), lemak kasar (LK), abu dan Beta-N. Data hasil penelitian dianalisis secara deskriptif.

Tabel 2. Persentase bahan pakan dalam formulasi ransum

\begin{tabular}{lc}
\hline \hline Bahan & Persentase $(\%)$ \\
\hline Dedak & 27,5 \\
Jerami kacang tanah & 25 \\
Tumpi jagung & 15 \\
Tongkol jagung & 27,5 \\
Molases & 3 \\
Premix & 1,4 \\
Biofermentor & 0,3 \\
Urea & 0,3 \\
\hline
\end{tabular}

\section{HASIL DAN PEMBAHASAN}

\section{Kualitas nutrisi pakan fermentasi berbasis limbah pertanian}

Pakan yang difermentasi dengan MOL yang berbeda menghasilkan penampilan yang baik sesuai dengan karakteristik produk-produk fermentasi, yaitu berbau tape, warna kecoklatan dan tidak tampak ada kontaminasi jamur. Hasil analisis proksimat yang menunjukkan kualitas nutrisi bahan pakan berbasis limbah pertanian yang difermentasi dengan MOL yang berbeda disajikan pada Tabel 3.

Tabel 3. Kualitas pakan berbasis limbah pertanian yang difermentasi dengan MOL yang berbeda

\begin{tabular}{lllllll}
\hline \hline Parameter & P0 $(\%)$ & P1 $(\%)$ & P2 $(\%)$ & P3 $(\%)$ & P4 (\%) & Rataan $(\%)$ \\
\hline BK & 48,87 & 47,80 & 46,00 & 49,35 & 51,97 & 48,80 \\
Abu & 4,86 & 4,47 & 4,81 & 5,29 & 5,67 & 5,02 \\
PK & 3,71 & 3,83 & 3,59 & 4,01 & 3,86 & 3,80 \\
SK & 18,70 & 20,05 & 17,52 & 20,65 & 18,30 & 19,04 \\
LK & 0,95 & 0,34 & 0,44 & 0,40 & 0,62 & 0,55 \\
BETA-N & 20,65 & 19,11 & 20,04 & 19,00 & 23,52 & 20,46 \\
\hline
\end{tabular}

$\mathrm{P} 0=\mathrm{EM} 4$

$\mathrm{P} 1=$ MOL rumen sapi

$\mathrm{P} 2=$ MOL rumen sapi + bonggol pisang

P3= Rumen sapi + rebung

$\mathrm{P} 4=$ Rumen sapi + daun gamal

Berdasarkan hasil analisis proksimat (Tabel 3), bahan kering dari sampel P2 lebih rendah dari sampel perlakuan lainnya. Rataan persentase BK dari pakan fermentasi sebesar 48,80\% dengan persentase tertinggi adalah P4 sebesar 51,97\%. Protein kasar tertinggi pada perlakuan P3 dengan persentase 4,01\% dan persentase serat kasar terendah pada perlakuan P2 yaitu $17,52 \%$. Secara umum pakan fermentasi dengan starter MOL 
dapat mensubtitusi penggunaan starter komersial (EM4). Tongkol jagung memiliki kandungan serat kasar sebesar 22,97\% dan protein kasar 6,23\% (Agustono et al. 2017). Adapun kecernaan limbah tongkol jagung yang diolah dengan amofer (amonia fermentasi) sebesar 48,32\% (Prastyawan et al. 2012).

Bahan bakan konvensional berupa rumput atau hijauan legum secara kualitas sudah baik diberikan ke ternak ruminansia, namun kuantitas yang diberikan masih terbatas, sehingga proses penggemukan atau pemeliharaan ternak kambing untuk perah belum optimal. Strategi penerapan pengolahan pakan komplit fermentasi sangat cocok diaplikasikan oleh peternak rakyat di Kabupaten Jember yang sebagian besar perekonomian Kabupaten Jember didukung oleh sektor pertanian. Pakan berbasis limbah pertanian yang dapat dimanfaatkan sebagai pakan ternak di Kabupaten Jember adalah limbah sisa tanaman (crop residues), hasil ikutan limbah tanaman (crop by products) dan limbah agroindustri (Wiryawan 2012). Produktivitas pertanian di Kabupaten Jember untuk tanaman pangan adalah padi sebesar 59,37 kw/ha, jagung 63,98 kw/ha, ubi kayu sebesar 133,80 kw/ha, ubi jalar 131,57 kw/ha, kedelai 20,47 kw/ha dan kacang tanah $15,13 \mathrm{kw} / \mathrm{ha}$ (BPS Kabupaten Jember 2017). Produk pertanian tersebut sangat berpotensi dijadikan pakan inkonvensional yang ekonomis dan mampu memenuhi kebutuhan nutrisi untuk hidup pokok ternak dan mampu menunjang produktivitas ternak termasuk reproduksi, produksi daging dan susu. Menurut BSN (2009) ternak sapi potong dalam pakan konsentratnya membutuhkan protein kasar sebanyak 13\%, lemak kasar 7\% dan kadar abu maksimal $12 \%$. Hasil fermentasi pakan berbasis limbah pertanian baik yang menggunakan biofermentor EM4 maupun MOL masih belum memenuhi standar mutu konsentrat untuk sapi potong.

Upaya peningkatan pakan berbasis limbah pertanian sudah dioptimalkan dengan berbagai perlakuan, yaitu secara fisik, dengan mencacah tongkol jagung dan rendeng kacang tanah menjadi ukuran yang lebih kecil. Kemudian dilakukan secara kimiawi dengan menambahkan urea untuk meningkatkan jumlah nitrogen sebagai sumber $\mathrm{N}$ untuk mikroba serta perlakuan fermentasi digunakan untuk menurunkan serat kasar dengan memecah ikatan lignoselulosa dan hemiselulosa. Fermentasi juga dapat meningkatkan kecernaan pakan yang memiliki serat tinggi (Prastyawan et al. 2012). Pengolahan pakan secara kimia dan biologis juga sangat bermanfaat untuk digunakan didaerah tropis khusunya di Indonesia. Proses ini digunakan untuk mengatasi tidak menentunya ketersedian hijauan dan pakan lain di daerah. Dengan melakukan pengolahan pakan diharapkan ketersedian pakan dapat dipenuhi sepanjang tahun, sehingga produksi daging dan susu dari ternak perah dan ternak pedaging dapat maksimal, sehingga kebutuhan akan produk ini dapat dipenuhi.

\section{Pengaruh MOL terhadap kualitas nutrisi pakan}

Mikroorganisme lokal (MOL) yang digunakan untuk fermentasi adalah berbasis cairan rumen sapi dengan penambahan beberapa bahan yang diketahui teridentifikasi mikroorganisme yang dapat menguntungkan baik untuk fermentasi pakan maupun pembuatan pupuk. MOL rumen mengandung berbagai bakteri yang berfungsi sebagai probiotik, diantaranya adalah Bifidobacterium 3,5 x $107 \mathrm{cfu} / \mathrm{ml}$, Bacillus 0,9 x 106 $\mathrm{cfu} / \mathrm{ml}$, Streptococcus 1,06 x $106 \mathrm{cfu} / \mathrm{ml}$, dan Lactobacillus 12,5 x $107 \mathrm{cfu} / \mathrm{ml}$ (Suryadi \& Prasetyo 2018). Menurut Indasah et al. (2018) MOL yang terbuat dari bonggol pisang mengandung Bacillus sebanyak 3,05 x 10², Azospirilum 1,3 x 106, dan bakteri selulotik sebanyak 6,65 x 105. Bakteri asam laktat dalam MOL mampu meningkatkan kecernaan pakan sedangkan bakteri selulitik mampu membantu memecah serat-serat yang ada dalam 
pakan terutama lignin dan hemiselulosa. Hasil penelitian menunjukkan bahwa pakan fermentasi berbasis limbah pertanian yang di beri MOL P3 (isi rumen dan bonggol pisang) mengandung serat kasar yang paling rendah. Hal tersebut karena enzim yang dikeluarkan oleh bakteri selulitik dalam MOL.

MOL bakteri asam laktat (Lactobacillus acidophilus, L. amylovorus, L. mucosae dan L. rhamnosus) yang diisolasi dari rumen sapi diketahui aman digunakan sebagai probiotik karena tidak ditemukan gen pembawa sifat virulensi dan juga memiliki sifat tahan terhadap antibiotik (Ficoseco et al. 2018). MOL yang mengandung probiotik Lactobacillus acidophilus dan Basilus subtilis dapat meningkatkan bobot badan yang lebih besar, meningkatkan efisiensi konversi ransum dan meningkatkan kecernaan bahan organik, protein kasar, energi dan NDF (neutral detergent fiber) serta meberikan dampak pada pertumbuhan bakteri yang menguntungkan dalam usus (Phuoc \& Jamikorn 2017).

Penelitian ini menunjukkan hasil fermentasi menggunakan MOL yang berbeda memberikan pengaruh yang hampir sama baik BK, SK, PK, LK, Abu dan BETA-N dibandingkan dengan biostarter komersial EM4. Berbeda dengan hasil penelitian (Mirwandono et al. 2018). Menjelaskan bahwa fermentasi menggunakan EM4 memberikan pengaruh yang berbeda secara signifikan pada BETA-N dan TDN (total digestible energy) pada fermentasi selama 3 hari. Semakin lama waktu fermentasi semakin baik kualitas nutrisi pakan, yaitu kandungan protein kasarnya akan semakin tinggi dan serat kasar akan semakin turun (Mirwandono et al. 2018). Selain itu penggunaan MOL untuk pengolahan pakan secara ekonomis lebih murah dan mudah untuk diterapkan di peternak rakyat karena sumber bahan-bahan untuk pembuatan MOL ini melimbah terutama di pedesaan. Pada seluruh perlakuan menunjukkan bahwa nilai nutrisi pakan fermentasi sangat rendah, yaitu dengan kisaran protein kasar 3,71-4,01\%. Hal tersebut dikarenakan bahan yang digunakan memiliki protein kasar yang sangat rendah, yaitu 3,55\% sehingga peningkatan proteinnya tidak terlalu tinggi meskipun sudah difermentasi dan ditambah urea.

\section{KESIMPULAN}

Kandungan serat kasar pakan fermentasi dari yang terendah yaitu P2 (17,52\%), P4 (18,30\%), P0 (18,70\%), P1 (20,05\%) dan P3 (20,65\%). Secara umum protein kasar pakan fermentasi masih rendah. Aplikasi MOL dari sumber alami berbahan dasar isi rumen, rebung, bonggol pisang dan daun Gamal dapat digunakan sebagai substitusi biostarter komersil EM4. Tongkol dan tumpi jagung merupakan biomassa yang dapat dimanfaatkan sebagai pakan ternak dengan aplikasi teknologi pengolahan pakan fermentasi dan penambahan bahan yang berprotein tinggi.

\section{DAFTAR PUSTAKA}

Agustono B, Lamid M, Ma A, Elziyad MT. 2017. Identifikasi limbah pertanian dan perkebunana sebagai bahan pakan inkonvensional di Banyuwangi. J Medika Vet. 1:1222.

AOAC Assosiation of Official Analytical Chemist. 2005. Official methods of analysis. 15th ed. Washington DC (USA): Assosiation of Official Analytical Chemist.

Badan Standarisasi Nasional. 2009. Pakan konsentrat-bagian 2: Sapi potong. SNI 3148:2009. Jakarta (Indonesia): Badan Standarisasi Nasional. 
Ficoseco CA, Mansilla FI, Maldonado NC, Miranda H, Fátima Nader-Macias ME, Vignolo GM. 2018. Safety and growth optimization of lactic acid bacteria isolated from feedlot cattle for probiotic formula design. Front Microbiol. 9:1-12.

Ginting N, Pase E. 2018. Effect of incubation time of sago (metroxylon sago) waste by local microorganism "ginta" on ph, crude protein, and crude fiber content. IOP Conference Series: Earth and Environmental Science. p. 130.

Heryandi Y, Adrizal, Nela N, Mahata MA. 2018. Carcass characteristics and organ development of broilers fedvfermented pineapple peel [Ananas comosus (L.) Merr] waste using a local microorganism solution derived from bamboo sprouts. Int Poult Sci. 17:229-233.

Imsya AR, Jakfar MA, Ginting S. 2017. Pengaruh rumput rawa dan limbah pertanian sebagai penyusun total mixed fiber (TMF) terhadap kecernaan serat kasar dan protein kasar secara in vitro. J Peternak Sriwij. 6:70-78.

Indasah, Wardani R, Eliana AD, Puspitasari Y, Rohmah M, Wulandari A. 2018. Potential microbe and quality of local microorganism solution (MOL) of banana hump based on concentration and old fermentation as bioactivator of railing. Indian J Public Health Res Dev. 9:803-808.

Khasanah, Purnamasari L, Suciati LP. 2018. Ppk Kelompok Ternak Lembah Meru Desa Wonoasri Kabupaten Jember melalui penerapan teknologi konsentrat fermentasi limbah pertanian sebagai pakan ternak. Laporan Pengabdian Masyarakat. Lembaga Penelitian dan Pengabdian kepada Masyarakat. Jember (Indonesia): Universitas Jember.

Lindung. 2015. Teknologi mikroorganisme EM4 dan MOL. Jambi (Indonesia): Agriculture Servive Office, Kementerian Pertanian.

Mirwandono E, Sitepu M, Wahyuni TH, Hasnudi, Ginting N, Siregar GAW, Sembiring I. 2018. Nutrition quality test of fermented waste vegetables by bioactivator local microorganisms (MOL) and effective microorganism (EM4). IOP Conference Series: Earth and Environmental Science. p. 122.

Phuoc TL, Jamikorn U. 2017. Effects of probiotic supplement (Bacillus subtilis and Lactobacillus acidophilus) on feed efficiency, growth performance and microbial population of weaning rabbits. Asian-Aust J Anim Sci. 30:198-205.

Prastyawan RM, Tampoebolon BIM, Surono. 2012. Peningkatan kualitas tongkol jagung melalui teknologi amoniasi fermentasi (Amofer) terhadap kecernaan bahan kering dan bahan organik serta protein total secara in vitro. Anim Agric J. 1:611-621.

Suryadi U, Prasetyo AF. 2018. Probiotics based on local microorganism as a subtitute of antibiotic growth promotor (AGP) on broiler productivity. 1st International Conference on Food and Agriculture 2018. IOP Conference Series: Earth and Environmental Science. p. 207.

Tafsin M, Khairani Y, Hanafi DN, Yunilas. 2018. In vitro digestibility of oil palm frond treated by local microorganism (MOL). International Conference on Agriculture, Environment, and Food Security. IOP Conference Series: Earth and Environmental Science. p. 122.

Umiyasih U, Wina E. 2015. Pengolahan dan nilai nutrisi limbah tanaman jagung sebagai pakan ternak ruminansia. Wartazoa. 18:127-136.

Van Soest PJ. 1982. Nutitional ecology of the ruminant. Ithaca. New York (USA): Cornell University Press.

Wiryawan GK, Tim Laboratorium Ilmu dan Teknologi Pakan. 2012. Pengetahuan bahan makanan ternak. Bogor (Indonesia): Fakultas Peternakan, Institut Pertanian Bogor. 
Yanti ES, Henuk LY, Ginting J, Yunilas, Tafsin M, Hamdan. 2018. Content of fibre fraction complete feed silage based waste corn (Zea mays) in the fermentation process with local microorganism "Probiotic MOIYL". AEFS 2018. IOP Conference Series: Earth and Environmental Science. p. 260. 